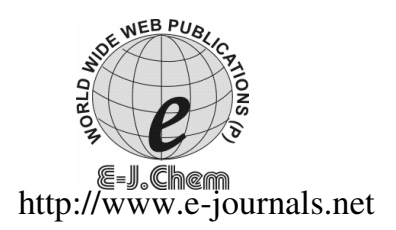

ISSN: 0973-4945; CODEN ECJHAO

E-Journal of Chemistry 2011, 8(2), 697-702

\title{
Effective Extraction of Heavy Metals from their Effluents Using Some Potential Ionic Liquids as Green Chemicals
}

\author{
A.RAJENDRAN ${ }^{*}$, D. RAGUPATHY, M. PRIYADARSHINI ${ }^{\S}$, A. MAGESH $^{\S}$, \\ P. JAISHANKAR ${ }^{\S}$, N.S. MADHAVAN ${ }^{\S}$, K. SAJITHA ${ }^{\S}$ and S. BALAJI ${ }^{\S}$ \\ ${ }^{\S}$ Department of Chemistry, Sir Theagaraya College \\ Chennai - 600 021, Tamilnadu, India \\ Department of Chemical Engineering \\ Kyungpook National University, Daegu 702-701, South Korea \\ annamalai_rajendran2000@yahoo.com
}

Received 27 July 2010; Revised 18 October 2010; Accepted 6 November 2010

\begin{abstract}
Synthesis of nine Task Specific Ionic liquids (TSILs), their characterization using ${ }^{1} \mathrm{H}$ NMR spectral studies and other physical properties and potential applications in the removal of certain heavy metals such as Nickel, Iron, Zinc, Copper and Lead has been studied. The removal of these heavy metals from the industrial effluents / contaminated water bodies using these ionic liquids has been proved to be more successful than conventional methods such as precipitation, cementation, reverse osmosis, ion exchange and adsorption.
\end{abstract}

Keywords: Heavy metals, Green chemicals, Effluents, Extraction, Task specific Ionic liquids

\section{Introduction}

Rapid industrialization and abnormal population growth enhance the serious aspects of water pollution ${ }^{1}$. The effluents often entering into the natural water stream include agricultural, industrial and domestic waters. Heavy metal pollution is considered to be more important than other type of water pollution as it causes serious ill effects ${ }^{2}$.

"Heavy metals" is a general collective form applying to the group of metals with an atomic density greater than $6 \mathrm{~g} \mathrm{~km}^{3}$. It is widely recognized and usually applied to the elements such as $\mathrm{Pb}, \mathrm{Cr}, \mathrm{Cu}, \mathrm{Mg}, \mathrm{Ni}$ and $\mathrm{Zn}$ which are commonly associated with pollution and toxicity problems. Some of the elements in this group are required by most living organisms in small for normal healthy growth, but excess concentration causes toxicity. Most of the micro nutrients owe their essentiality to being constituents of enzymes and other important proteins involved in key metabolic pathways. Micronutrients will result in a shortage of the enzymes, which lead to metabolic dysfunction causing diseases. 
Tamilnadu is a state in which many chemical industries dealing with heavy metals such as lead, chromium, zinc, iron and arsenic, copper are located. In places where these chemical industries are located, people of both sexes irrespective of their age get afflicted with chronic diseases, which are mainly attributed to drinking water contaminated with these heavy metals discharged from the nearby industries. Therefore, removal of these metals from the drinking water sources has become the burning issue for both industries and the society at large. Several attempts have been made so far by environmentalists all over the globe to remove such heavy metals from the effluent discharged from chemical industries. Nevertheless they have not succeeded with cent percent in their tasks which may be due to lack of proficiency, expensive methods and other technical flaws.

The use of task specific ionic liquid (TSILs) as potential extracting agents for the removal of heavy metals such as lead, mercury, cadmium, chromium and so on explores interesting results $^{3-6}$. The removal of these heavy metals from the industrial effluents / contaminated water bodies using these ionic liquids has been proved to be more successful than conventional methods such as precipitation, cementation, reverse osmosis, ion exchange and adsorption ${ }^{7-9}$. Therefore in this present work, we have attempted to remove heavy metals such as nickel, iron, zinc, copper and lead form their effluents using newly synthesized certain ionic liquids.

\section{Experimental}

The compounds tetrapropylammonium benzoate (ILA), tetrapropylammonium salicylate (ILB), tetrapropylammonium anthranilate (ILC), tetrabutylammonium benzoate (ILD), tetrabutylammonium salicylate (ILE), tetrabutylammonium anthranilate (ILF), tricaprylmethylammonium benzoate (ILG), tricaprylmethylammonium salicylate (ILH) and tricaprylmethylammonium anthranilate (ILI) were synthesized using deprotanationmetathesis route by stirring equimolar amounts of aliquot as a precursor and selected Bronsted acids in a sodium hydroxide solution. Deprotanation of the acid followed by anion metathesis led to the desired ionic liquids. This is shown in scheme 1. Aliquot is actually an ionic liquid itself and is regarded as a 2:1 mixture of tricaprylmethylammonium chloride / tetrabutylammonium bromide tetrapropylammonium bromide and benzoic acid/salicylic acid/anthranilic acid. Interestingly, including a tricaprylmethylammonium chloride in molar weight calculation, a mean value of $404.17 \mathrm{~g} / \mathrm{mol}$ is also obtained for aliquot and was therefore used throughout our synthesis. Similar procedure was adopted for the calculation of molecular weight of the other two precursors.

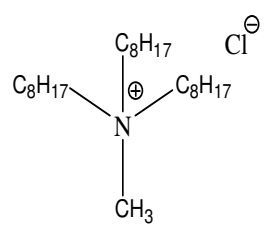<smiles>O=C(O)C1=C(S)C=CC=[C+]1</smiles>

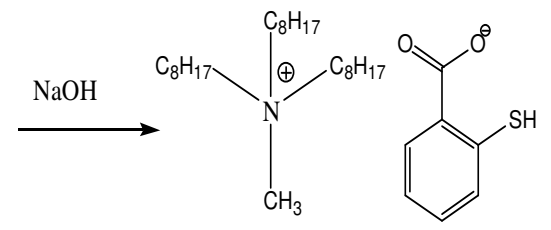

Scheme 1. Synthesis of tricaprylmethylammonium thiosalicylate ionic liquid (A representative reaction)

\section{Extraction of $\mathrm{Zn}, \mathrm{Ni}, \mathrm{Pb}, \mathrm{Fe}$ and $\mathrm{Cu}$ using various ionic liquids}

About 1.0/0.5/1.0/0.5/0.5 mL of each ionic liquid was mixed with 40/8.0/40/10/10 mL of effluent of $\mathrm{Zn} / \mathrm{Ni} / \mathrm{Pb} / \mathrm{Fe} / \mathrm{Cu}$. These mixtures of solutions were shaken well for an hour and centrifuged at $3500 \mathrm{rpm}$. The water phase separated from the ionic liquid was taken for measurement. $\mathrm{Zn}$ and $\mathrm{Pb}$ were determined by gravimetric and $\mathrm{Fe}$ and $\mathrm{Cu}$ were determined by colorimetric methods. 


\section{Results and Discussion}

Table 1 displays some of the physicochemical properties of all the newly synthesized nine TSILs such as the nature, molecular weight and the density. The nature of the ionic liquids was inspected visually, molecular weight was determined by Rast's method and density was determined by measuring the weight of the ionic liquids for their known volume.

Table 1. Physicochemical properties of newly synthesized ionic liquids

\begin{tabular}{ccccc}
\hline Entry & Ionic liquid & Nature & Molecular weight, g/mol & Density, g/cm ${ }^{-1}$ \\
\hline 111451.1. & ILA & Viscous & 307 & 0.891 \\
2. & ILB & Viscous & 324 & 0.889 \\
3 & ILC & Viscous & 322 & 1.145 \\
4 & ILD & Solid & 363 & 0.867 \\
5 & ILE & Viscous & 380 & 0.870 \\
6 & ILF & Viscous & 378 & 0.874 \\
7 & ILG & Viscous & 489 & 0.800 \\
8 & ILH & Viscous & 505 & 0.759 \\
9 & ILI & Viscous & 504 & 0.747 \\
\hline
\end{tabular}

Table 2 reveals the solubility of all the nine ionic liquids in various organic and inorganic solvents such as water, methanol, ethanol, chloroform, dimethylformamide, tetrahydrofuran, ether and acetone at room temperature. It was inferred that the ionic liquids tetrabutylammonium benzoate is much soluble in solvents with high polarity and dielectric constant like water and methanol and was found to be partially soluble in ethanol (less dielectric constant) and completely insoluble in solvents like chloroform, dimethylformamide, tetrahydrofuran, ether, acetone. This observation clearly shows that these ionic liquids are highly polar.

Table 2. Solubility of the ionic liquids in various solvents

\begin{tabular}{|c|c|c|c|c|c|c|c|c|}
\hline $\begin{array}{l}\text { Ionic } \\
\text { liquid }\end{array}$ & $\mathrm{r}$ & $\begin{array}{l}\text { Methyl } \\
\text { alcohol }\end{array}$ & $\begin{array}{c}\text { Ethyl } \\
\text { alcohol }\end{array}$ & $\mathrm{m}$ & DMF & $\mathrm{HF}$ & ther & Ac \\
\hline ILA & & Soluble & Soluble & & & & & \\
\hline ILB & le & $\begin{array}{c}\text { Partially } \\
\text { soluble }\end{array}$ & $\begin{array}{c}\text { Partially } \\
\text { soluble }\end{array}$ & Inso & $\begin{array}{l}\text { Part } \\
\text { Sol }\end{array}$ & $\begin{array}{c}\text { Part } \\
\text { Sol }\end{array}$ & ple & Insoluble \\
\hline ILC & Solv & $\begin{array}{c}\text { Partially } \\
\text { Soluble }\end{array}$ & $\begin{array}{c}\text { Partially } \\
\text { Soluble }\end{array}$ & Insoluble & Insoluble & Insoluble & ible & $\begin{array}{l}\text { Partially } \\
\text { Soluble }\end{array}$ \\
\hline ILD & le & Soluble & Sol & $\begin{array}{l}\text { Par } \\
\text { Sol }\end{array}$ & $\begin{array}{c}\text { Partially } \\
\text { Soluble }\end{array}$ & & & $\begin{array}{c}\text { Partially } \\
\text { Soluble }\end{array}$ \\
\hline ILI & le & Insoluble & Insoluble & & $\begin{array}{c}\text { Partially } \\
\text { Soluble }\end{array}$ & Ins & & able \\
\hline ILF & & le & $\begin{array}{l}\text { ly } \\
\text { le }\end{array}$ & ble & In & & & Insoluble \\
\hline ILG & le & $\begin{array}{c}\text { Partially } \\
\text { Soluble }\end{array}$ & $\begin{array}{c}\text { Partially } \\
\text { Soluble }\end{array}$ & uble & $\begin{array}{c}\text { Partially } \\
\text { Soluble }\end{array}$ & $\begin{array}{l}\text { Partially } \\
\text { Soluble }\end{array}$ & ible & $\begin{array}{l}\text { Partially } \\
\text { Soluble }\end{array}$ \\
\hline ILH & & $\begin{array}{c}\text { Partially } \\
\text { soluble }\end{array}$ & $\begin{array}{l}\text { Partially } \\
\text { Soluble }\end{array}$ & Insoluble & $\begin{array}{c}\text { Partially } \\
\text { Soluble }\end{array}$ & $\begin{array}{l}\text { Partially } \\
\text { Soluble }\end{array}$ & le & $\begin{array}{l}\text { Partially } \\
\text { Soluble }\end{array}$ \\
\hline ILI & Insol & Soluble & $\begin{array}{l}\text { Partially } \\
\text { Soluble }\end{array}$ & $\begin{array}{c}\text { Partially } \\
\text { Soluble }\end{array}$ & $\begin{array}{c}\text { Partially } \\
\text { Soluble }\end{array}$ & $\begin{array}{l}\text { Partially } \\
\text { Soluble }\end{array}$ & Insoluble & $\begin{array}{c}\text { Partially } \\
\text { Soluble }\end{array}$ \\
\hline
\end{tabular}


The structure of all the above newly synthesized ionic liquids was investigated by ${ }^{1} \mathrm{H}$ NMR spectral method. As prepared ionic liquids contain a carboxylic functional group in addition to another functional group like thiol group, they were evaluated as potential extracting agents for heavy metals like cadmium, from their different aqueous solution. Keeping this view in mind, in the present work, we have attempted the removal of certain heavy metals such as zinc, nickel, lead, iron and copper from their aqueous solutions using ultra pure water.

For the removal of zinc from their aqueous solution (Table 3) tricaprylmethylammonium salicylate were found to be better than other ionic liquids employed. The following is the decreasing order of the efficiency of removal of zinc using various Ionic liquids.

$$
\mathrm{ILH}>\mathrm{ILB}>\mathrm{ILA}>\mathrm{ILD}>\mathrm{ILC} \simeq \mathrm{ILI}>\mathrm{ILF}>\mathrm{ILH}>\mathrm{ILE}
$$

As far as the \% removal of nickel is concerned, it is inferred that almost all the nine ionic liquids were proved to be good and potential extracting agents from their aqueous solution. However, tetrabutylammonium anthranilate, tetrabutylammonium salicylate were found to be better than other ionic liquids employed. The following is the decreasing order of the efficiency of removal of nickel using various ionic liquids, ILF> ILE > ILH> ILD> ILC $>$ ILA $>$ ILG ILI $>$ ILB. A look at the \% removal of $\mathrm{Pb}$, the following decreasing order is observed using various ionic liquids, ILC $\sim$ ILH $>$ ILE $>$ ILA $>$ ILG $>$ ILF $>$ ILB $>$ ILD $~$ ILI .As far as the removal of Iron is concerned, tetrabutylammonium salicylate, tetrapropylammonium benzoate were found to be better than other Ionic liquids employed. The following is the decreasing order of the efficiency of removal of iron using various ionic liquids ILE> ILA $>$ ILF $>$ ILD ILG $>$ ILI $>$ ILH $>$ ILB $~ I L C$. For the removal of copper from their aqueous solution, tricaprylmethylammonium anthranilate was found to be better than other Ionic liquids employed. The following is the decreasing order of the efficiency of removal of copper using various Ionic liquids, ILI $>$ ILH $>$ ILC $\sim$ ILF $>$ ILG $>$ ILB $>$ ILA $\sim$ ILD ILE.

Table 3. \% Removal of zinc, nickel, lead, iron and copper using various ionic liquids

\begin{tabular}{cccccc}
\hline \multirow{2}{*}{ Ionic liquid } & \multicolumn{5}{c}{ \% Removal of } \\
\cline { 2 - 6 } & $\mathrm{Zn}$ & $\mathrm{Ni}$ & $\mathrm{Pb}$ & $\mathrm{Fe}$ & $\mathrm{Cu}$ \\
\hline ILA & 54.5 & 60.0 & 82.4 & 88.4 & 11.7 \\
ILB & 65.8 & 52.7 & 70.6 & 40.4 & 26.1 \\
ILC & 43.4 & 63.0 & 88.2 & 40.4 & 34.9 \\
ILD & 48.8 & 66.0 & 44.1 & 82.6 & 11.7 \\
ILE & 12.9 & 68.0 & 85.3 & 94.2 & 11.7 \\
ILF & 43.1 & 84.7 & 72.1 & 86.5 & 34.9 \\
ILG & 19.3 & 53.4 & 73.5 & 82.6 & 29.09 \\
ILH & 93.3 & 66.6 & 88.2 & 46.1 & 44.6 \\
ILI & 43.4 & 54.1 & 44.1 & 63.4 & 47.5 \\
\hline
\end{tabular}

From the Table 3, it is inferred that almost all the nine Ionic liquids were proved to be good and potential extracting agents for the removal of Iron from their aqueous solution. This removal procedure is regarded to as more sustainable, as no volatile and flammable organic solvents are needed. Other environmental friendly, low cost bio material, like for example, bio-film covered granular activated carbon or crab shells, showing absorbance of organic residue or slow sorption kinetics respectively are outnumbered by this novel technique displaying an undistributed fast metal uptake and a high affinity for heavy metals like Zn, $\mathrm{Ni}, \mathrm{Pb}, \mathrm{Fe}$ and $\mathrm{Cu}$ under neutral conditions, even in a complex natural matrix.

As the prepared ionic liquids contain carboxylic / thiocarboxylic / anthranilic functionality they were evaluated as potential extracting agents for removal of heavy 
metals from industrial effluents. To evaluate the extracting potential of these ionic liquids under neutral conditions and the influence of a natural buffered fluvial system, the $\mathrm{pH}$ value of the water samples was kept at the $\mathrm{pH}$ as measured after spiking with standard solutions of $\mathrm{Zn}, \mathrm{Ni}, \mathrm{Pb}, \mathrm{Fe}$ and $\mathrm{Cu}$. Flame atomic absorption spectroscopy was also used for quantization of these heavy metals present in the effluents in addition to other methods. It is believed that heavy metals are snatched away by the ionic liquids by the well documented process called sequestration. Compared to other extracting agents, working well under neutral conditions, on which research was recently published, the ionic liquids which are proposed in this method display some interesting advantages: the extracting efficiency lies greater than other extracting agents ${ }^{9}$ and their use may be regarded to use as more sustainable, as no volatile and flammable organic solvents are needed. Other environmental friendly, low - cost biomaterials, for example, bio film covered granular activated carbon, or crab shells, demonstrating adsorption of organic residues or slow adsorption kinetics, respectively are out numbered by these proposed ionic liquids in this method by displaying an undisturbed fast metal uptake and a high affinity for these heavy metals under neutral conditions, even in a complex neutral matrix. The ionic liquids used in this investigation removed heavy metals such as $\mathrm{Zn}, \mathrm{Ni}, \mathrm{Pb}, \mathrm{Fe}$ and $\mathrm{Cu}$ from their effluents with efficiency remarkably greater than other conventional methods such as chemical precipitation, co-precipitation, coagulation, evaporator recovery process, reverse osmosis, electrolytic recovery and adsorption.

After the extraction procedure in this method is over, the ionic liquid present in the organic layer was separated using separating funnel under controlled pressure. The recovered ionic liquid was reused successively to the same kind of extraction method and it was ascertained that the extracting efficiency remains same at least for half-a-dozen times. Not only the extraction efficiency is greater but also the other advantages like the following are entertained

(i) No requirement of volatile and flammable organic solvents

(ii) More sustainability

(iii) Eco \& environmentally friendly procedure

(iv) Fastness and reliability

(v) Recoverability and reusability of ionic liquid hence more economical

\section{Conclusion}

The task specific ionic liquids were proved to be excellent extracting agents for heavy metals from their aqueous solutions. When these water-insoluble (hydrophobic) TSILs ionic liquids come in contact with effluents containing heavy metal ions, they snatch away the metal ions from the effluents and sequester them in the hydrophobic task specific ionic liquid. The ionic liquid was synthesized by simple metathesis route and characterized by analyzing spectral and physicochemical properties. This task specific ionic liquid was proved to be an excellent extractor of heavy metals such as $\mathrm{Zn}, \mathrm{Ni}, \mathrm{Pb}, \mathrm{Fe}$ and $\mathrm{Cu}$ from the tannery effluents. This removal procedure using ionic liquid outnumbered the conventional removal processes like adsorption, chemical precipitation, reverse osmosis, evaporator recovery process and electrolytic recovery in terms of removal efficiency, fastness, ejection of no hazardous \& inflammable chemicals and ability to recover and reuse. This piece of work will also create a kind of enthusiasm among the scientists especially the chemists and environmentalists to investigate more on the synthesis of similar hydrophobic ionic liquids and their utilization for the removal of heavy metals from the contaminated water resources and industrial effluents. 


\section{Acknowledgment}

The author AR is thankful to the UGC, New Delhi for the financial support rendered for the UGC major research project [F.No:35-147 / 2008 (SR)]. The author also expresses his gratitude to the Principal and The Management of Sir Theagaraya College, Chennai - 21 also for all the help given.

\section{References}

1 Logsdon B I and Cullote J M, Waste water Association, 1972, 9, 418.

2. Junli C and Trost B M, The National Academy of Science of the USA,.2008, 36(105), 13197-13202.

2. Ganesan K and Alias Y, Int J Mol Sci., 2008, 9, 1207-1213.

3. Visser A E, Swatloski R P, Reicherit W M, Mayton R, Sheff S, Weierzbicki A, Davis J H and Rogers R D, Chem Commum., 2001, 1, 135-136.

4. Visser A E, Swatloski R P, Reicherit W M, Mayton R, Sheff S, Weierzbicki A, Davis J H and Rogers R D, Environ Sci Technol., 2002, 36, 2523-2529.

5. Holbery J D, Visser A E, Pear S K, Reichert W M, Swatloski R P, Broker G A and Rogers R D, Green Chem., 2003, 5, 129-135.

6. Ouadi A, Gadenna B, Hesemann P, Moreau JJE, Billard I, Gaillard C, Mekki S and Moutiers G, Chem Cur J., 2006, 12, 13074-3081.

7. Papaicomomou N, Lee J M, Salimen J, Stosch M V and Prausnitz M J, J Chem Engg Data, 2007.doi:10.1021/i.e 0706562.

8. Mikkola J P, Virtanen P and Sjoholm R, Green Chem.., 2006, 8, 250.

9. Kogelnig D, Stojanovic A, Galanski M, Groessl M, Jirse F, Krachle R and Keppler B K, Terahedron Lett., 2008, 49, 2782-2785.

10. Barriada J L, Herrero R, Rodríguez P and Sastre de Vicente M E, J Chem Technol Biotechnol., 2007, 82(1), 39-46. 


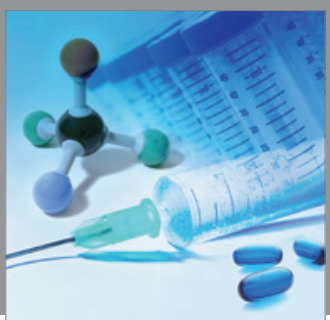

International Journal of

Medicinal Chemistry

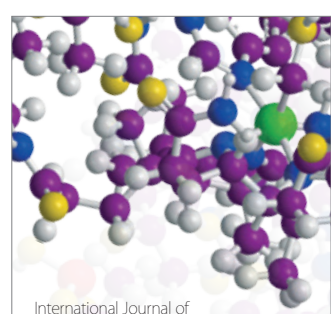

Carbohydrate Chemistry

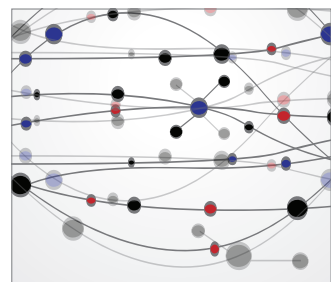

The Scientific World Journal
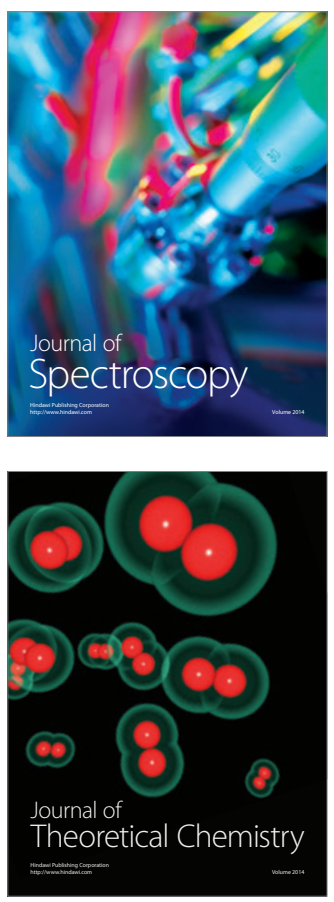
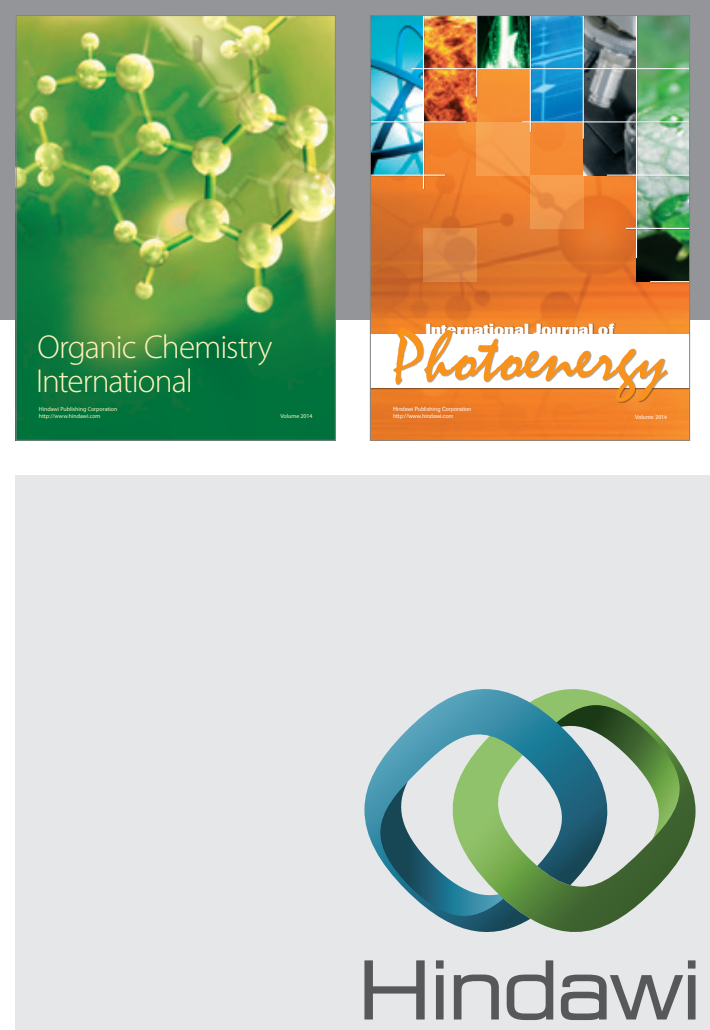

Submit your manuscripts at

http://www.hindawi.com
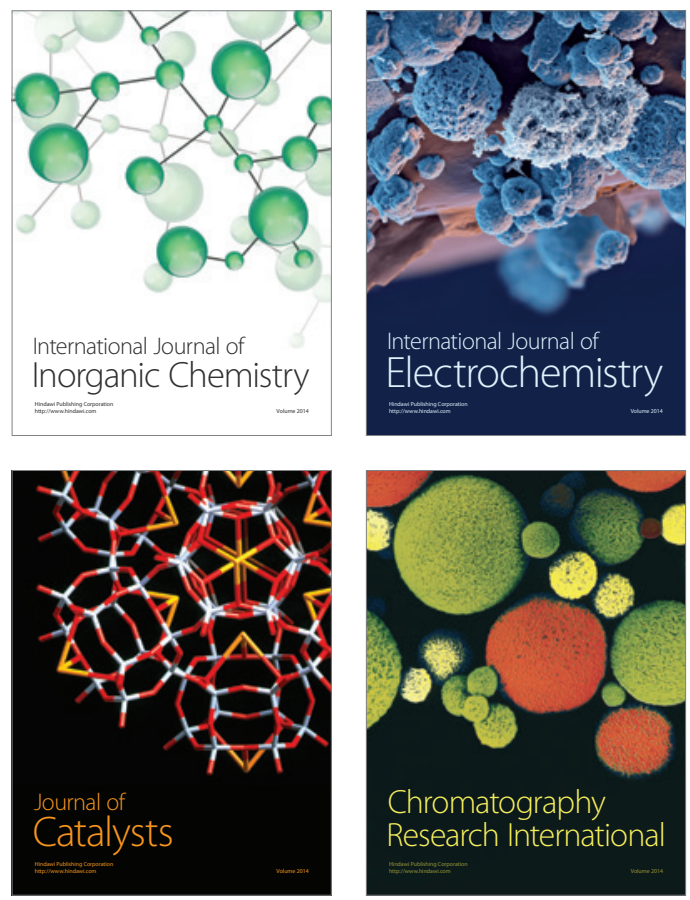
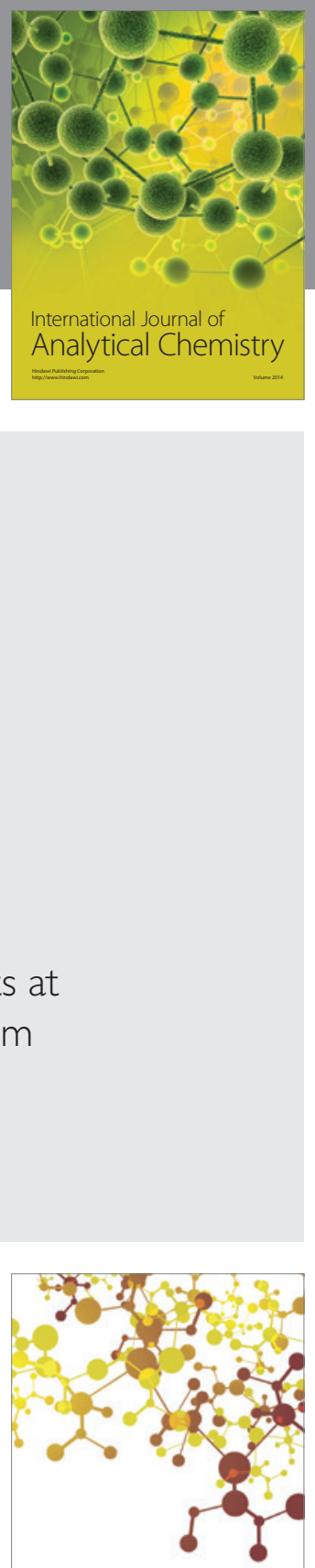

Journal of

Applied Chemistry
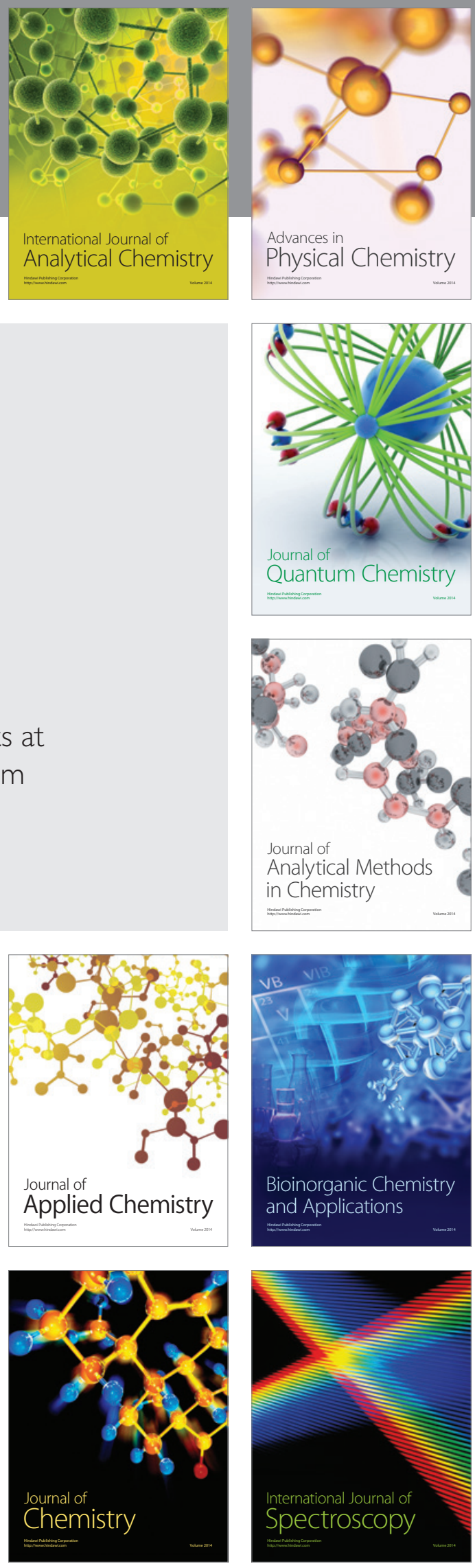